\title{
Natural History and Farming
}

\author{
Dr. George Ledingham
}

The Regina Natural History Society has had an invitation to present a brief to the Royal Commission on Agriculture and Rural Life. A Committee was appointed. The members of this committee felt that a worthwhile brief might be presented if notice were included in this "Blue Jay" and if a large number of the members of the Saskatchewan Natural History Society contributed ideas and facts.

The Commission is investigating the whole question of the present and future welfare of our agricultural profession in Saskatchewan. The brief from the Saskatchewan Natural History Society will try to avoid the obvious problems of home conveniences, roads, education, etc., and will deal only with problems which we feel touch closely on the aims and objects of our own Society.

We believe that the members of the Natural History Society get more enjoyment out of life than do other people. We would like you to explain why this is and, if pcssible, give facts supporting the idea that appreciation of natural history tends to keep people on the farm and increase their enjoyment of life. As a basis for discussion we are suggesting the following problems:

1. The deveolpment of an appreciation of the beauties of the prairies and its plants and animals, and of farming as a way of life. The solution of this problem would include development and expansion of the work of the "Blue Jay," and of the Museum and its film program.

2. The provision of recreational facilities by maintaining small free parks and natural sites for hiking, boating, camping and nature study in the summer, and by developing museums where people may see beautiful paintings and habitat groups in the winter. Such places, within easy driving distance of all the people would aid in solving problems one and three, and would also have a considerable effect on the health of the people.

3. The conservation of native plants and animals by the setting aside of many small protected zones in each of the soil and vegetation regions of the province. These areas should not be open to tourist or picnickers, but would be important primarily in preventing extinction of any more of our wild life.

Which of these problems is most important, and are there other problems which we might present? Facts are required to support our statements, so please send us facts. The value of our brief will be in direct proportion to the number of contributions so, if you feel strongly on any question touched on in this article, please write in as soon as possible to:

Dr. George Ledingham, Regina College, Regina.

\section{PATRONS FOR 1953}

John B. Richardson, Winnipeg $\$ 20.00$

Dr. C. J. Houston, Yorkton ...... 10.00

Yorkton Natural History Society

Constance Orman, Stoughton (11 Gift Subscriptions) ....

D. W. Matheson, Yorkton

(9 Gift Subscriptions)

Dr. Stuart Houston, Yorkton (5 Gift Subscriptions)
Elizabeth Hubbard, Grenfell ...

Allan Hudson, Mortlach

Ernie Symons, Rocanville

G. W. Carmichael, Montreal ...

N. S. Dunstan, Strongfield

D. R. Robinson, Saskatoon

Fred Robinson, Regina 